\title{
THE PATHOGENICITY OF AN ISOLATE OF INFECTIOUS BURSAL DISEASE VIRUS IN GUINEA FOWLS
}

\author{
J. O. A. OKOYE and G.C. OKPE \\ Department of Veterinary Pathology and Microbiology, \\ University of Nigeria, Nsukka, Nigeria
}

Received March 28, 1988

A b s $t r a c t$

$0 \mathrm{k} \circ \mathrm{y} \mathrm{e}$ J. O. A. , G. C. $0 \mathrm{k} p$ e: The Pathogenicity of An Isolate of Infectious Bursal Disease Virus in Guinea Fowls. Acta vet. Brno, 58, 1989:91-96.

Five weeks old guinea fowls were inoculated intraocularly with a $20 \%$ bursal suspension containing a local Nigerian isolate of infectious bursal disease virus (IBDV) which had a bursal lesion titre of $10^{4.5}$ per $0.5 \mathrm{ml}$. No clinical signs were observed. Gross lesions were absent and microscopic lesions were not found in the bursa, spleen and kidney on days 3 and 5 post infection (PI). IBDV antigen was not detected in the bursa. Tests for IBDV precipitins in serum samples obtained on day $14 \mathrm{PI}$ were also negative.

IBDV, Guinea fowl, experimental infection.

Infectious bursal disease (IBD) is mainly a disease of domestic fowl $(0 \mathrm{k} \circ \mathrm{y} \mathrm{e}$ 1984). Turkeys have been observed to respond serologically to IBD virus (IBDV) infection without clinical signs ( $\mathrm{e} i \mathrm{~s} \mathrm{~m}$ a and H i t c h n r 1978; P e e $1 \mathrm{man}$ and He 11 e r 1981 and 1983). $M \quad c \quad N \quad u \quad t \quad y$ et al. (1979) isolated IBDV from turkeys suffering from natural diarrhoea. Immunosuppression has also been reported in IBDV infection in turkeys even in the absence of any clinical or pathological changes ( $\mathrm{Ch} \mathrm{u} \mathrm{h}$ and $\mathrm{Th} \circ \mathrm{r} \mathrm{s} \mathrm{e}$ 1984). Serological evidence of infection has been described in village weaver and condonbleu ( $\mathrm{N}$ a $\mathrm{w}$ a $\mathrm{he}$ et al. 1978). Pigeons have been found resistand (F $\mathrm{r}$ i $\mathrm{t} \mathrm{z} \mathrm{s} \mathrm{h}$ e et al. 1981) but natural IBD has been recorded in artificially reared pheasants ( $\mathrm{L} \circ \mathrm{u} \mathrm{z} i \mathrm{~s}$ et $a l$. 1979). E d $g$ a $r$ and $C h$ (1965) reported the death of English sparrows on a farm with an outbreak of IBD but provided no confirmatory data. Y a m a d a et al. (1982) failed to induce clinical IBD in ducks but the birds responded serologically. No antibody against IBDV was detected in egg yolk from quails, ducks, geese, bantams or pigeons by $\mathrm{H} i \mathrm{r} O \mathrm{~s} e$ and $\mathrm{H}$ i r a $i$ (1976).

However, there is still limited information on the susceptibility of some avian species to IBDV infection. This paper describes the pathogenicity of an isolate of IBDV in guinea fowls. 
F 1 o c k h i s t o r y a n d I B D V

The IBDV was obtained as a $20 \%$ suspension, in phosphate buffered saline (PBS), of the bursa of chickens that died of outbreaks of IBD confirmed by methods already described by $0 \mathrm{k} \circ \mathrm{y} e$ and $\mathrm{U} z \circ \mathrm{u} \mathrm{k} \mathrm{u}$ (1981).

The suspension was found to contain bursal lesion $\left(\mathrm{BL}_{50}\right)$ titre of $10^{4.5} / 0.5 \mathrm{ml}$ by method of $\mathrm{Re} \mathrm{e}$ and $\mathrm{M} \mathrm{u}$ e $\mathrm{n} h$ (1938).

The guinea fowls were obtained at one day of ag $\epsilon$ and brooded by the deep litter system. At 5 weeks of age they were divided into 2 groups (A and B), placed in cages and housed separately. Group A fowls were each given a total of $0.05 \mathrm{ml}$ of the bursal suspension in the 2 eyes. Group B birds were each similarly treated with $20 \%$ normal bursal suspension in PBD (uninfected control).

Exam inat ion for C 1 in i c a 1 a n d Pathollog $\mathrm{i}$ c a 1 C h a n g e s

Both groups were observed twice daily for clinical signs. On days 3 and 5 post infection (PI) 3 infected and 2 control birds were sacrificed and examined for gross lesions. The weights of the carcass and bursa were obtained for each bird and the bursal \% of carcass weight was determined. The bursa, spleen and kidney of the birds were prepared for histopathology.

Examination for IBD antigen in the b u r s a

Bursas of birds sacrificed in both groups on days 3 and 5 PI were suspended with equivalent weight/volume of PBS to make a $50 \%$ suspension. The suspension was tested for. IBDV antigen by agar gel diffusion precipitation test (AGDT) using the method and agar described by $0 \mathrm{k} \circ \mathrm{y} e$ and U z O k k u (1981).

Examination for I B D $\mathrm{f}$ precipitins

Blood was collected from 5 of the guinea fowls at day 0 before infection, from 5 infected and 5 uninfected 14 days PI. Sera were harvested and inactivated at $56^{\circ} \mathrm{C}$ for $30 \mathrm{~min}$. The samples were tested for IBDV precipitins in AGDT as described above.

\section{Results}

\section{Clinical and Pathological changes}

No clinical signs were observed in both groups of guinea fowls throughout the experiment. Neither gross nor micro- 
scopic lesions were seen in the sacrificed birds. The weights of the carcass, bursa and bursal $\%$ of carcass weights are shown in Table I. The figures were statistically analysed using sample $t$-test and there was no significant difference between the 2 groups ( $P>0.05$ ).

\section{Table 1}

Bursal and carcass weights of IBDV infected and noninfected guinea fowls

\begin{tabular}{|c|c|c|c|c|c|c|c|}
\hline $\begin{array}{c}\text { Days } \\
\text { P1 }\end{array}$ & $\begin{array}{l}\text { Infection } \\
\text { history }\end{array}$ & $\begin{array}{c}\text { Carcass } \\
\text { wt. }\end{array}$ & $\begin{array}{l}\text { Bursal } \\
\text { wt. } \\
\text { (gm) }\end{array}$ & $\begin{array}{c}\text { Bursal \% } \\
\text { of carcass } \\
\text { wt. }\end{array}$ & $\begin{array}{c}\text { Mean } \\
\text { carcass } \\
\text { wt. }\end{array}$ & $\begin{array}{c}\text { Mean } \\
\text { bursal } \\
\text { wt. }\end{array}$ & $\begin{array}{c}\text { Mean bursal } \\
\% \text { of } \\
\text { carcass wt }\end{array}$ \\
\hline \multirow[t]{2}{*}{3} & $\begin{array}{c}\text { Group B } \\
\text { (noninfected) }\end{array}$ & $\begin{array}{l}111.00 \\
126.60\end{array}$ & $\begin{array}{l}0.04 \\
0.06\end{array}$ & $\begin{array}{l}0.04 \\
0.05\end{array}$ & 118.80 & 0.05 & 0.05 \\
\hline & $\begin{array}{c}\text { Group A } \\
\text { (infected) }\end{array}$ & $\begin{array}{l}143.20 \\
122.20 \\
119.40\end{array}$ & $\begin{array}{l}0.06 \\
0.06 \\
0.05\end{array}$ & $\begin{array}{l}0.04 \\
0.05 \\
0.04\end{array}$ & 128.27 & 0.06 & 0.04 \\
\hline 5 & $\begin{array}{c}\text { Group B } \\
\text { (noninfected) }\end{array}$ & $\begin{array}{l}132.20 \\
101.10\end{array}$ & $\begin{array}{l}0.06 \\
0.04\end{array}$ & $\begin{array}{l}0.05 \\
0.03\end{array}$ & 116.65 & 0.05 & 0.04 \\
\hline & $\begin{array}{c}\text { Group A } \\
\text { (infected) }\end{array}$ & $\begin{array}{l}162.6 \\
100.1 \\
102.4\end{array}$ & $\begin{array}{l}0.07 \\
0.04 \\
0.05\end{array}$ & $\begin{array}{l}0.05 \\
0.04 \\
0.04\end{array}$ & 121.70 & 0.05 & 0.04 \\
\hline
\end{tabular}

$P>0.05$

AGDT

The test for IBDV antigen in the bursa of the birds sacrificed in the 2 groups gave negative results. The test for IBDV precipitins in pre-infection and post infection sera also gave negative results. In both tests positive controls gave positive results within $36 \mathrm{hr}$.

Discussion

Reports of experimental infection of guinea fowls with IBDV appear to be scarce. But $\mathrm{N}$ a w a $\mathrm{t} h \mathrm{e}$ et al. (1978) and $\mathrm{O} \mathrm{k} \circ \mathrm{y} \mathrm{e}$ (1988) after serological surveys of guinea 
fowl farms by AGDT found no evidence of IBDV infection in the birds. The clinical and pathological results of this investigation indicate that IBDV may not be pathogenic to guinea fowls. AGDT has been found less sensitive than virus isolation, fluorescent antibody test, serum neutralization test and enzyme-linked immunosorbent assay in detecting IBDV injection ( $\mathrm{d} e$ 1975; $M$ a $r$ q $u-$ a $r d t$ et al. 1980; $H$ o $w$ i and $T h$ o $r$ e $n$ 1981; $\mathrm{P}^{-} \mathrm{h} i \mathrm{l} \quad \mathrm{i} \mathrm{p} \mathrm{s}$ 1981). Hence more work is needed to determine if the birds are completely resistant to IBDV infection.

Guinea fowls exist in the wild and are often reared in the same premises or areas with susceptible chickens. It is therefore necessary to determine if they play any role in the spread of the disease to chickens.

\section{Patogenita isolátu viru infekční bursitidy u perličky domácí}

Kuřata perličky domácí byla ve věku 5 týdnů intraokulárně inokulována 20\%ní bursální suspenzí s obsahem lokálního nigerijského isolátu viru infekční bursitidy (IBDV) s titrem bursálních lézí $10^{4.5} \mathrm{v} 0 ? 5 \mathrm{ml}$. Klinické známky onemocnění pozorovány nebyly. Patologické léze rovněž nebyly nalezeny, patohistologický nález na bursa Fabrizii, slezině a ledvinách byl 3. a 5 . den po infekci negativní. IBDV antigen $v$ burse nalezen nebyl, negativní byly i testy na detekci IBDV precipitinů ve vzorcích krevního séra, odebraných 14. den po infekci.

Tyto nálezy naznačují, že pro perličku domácí IBDV patogenní není.

\section{Патогенность изолята вируса инфекционного бурсита у цесарки}

цыплят цесарки в возрасте 5 недель инокулировали 208 бурсалыной сүспензией с содержанием местного нигерийского изолята вируса инфекционного бурсита 
(IBDV) с титром бурсальных поврехдений $10^{4.5}$ в 0,5 мл. Клинические признаки заболевания не наблюдали. Патологические повреждения не были также выявлены, патогистологический анализ на bursa Fabrizii, селезенке и почках 3 и 5 сутки после инфекции был негативным. Антиген IBDV в сүмке не обнаружен, негативными были также тесты детектирования IBDV преципитинов в образцах кровяной Сыворотки, взятых через две недели после инфекции.

Полученные данные дают возможность предположить, что IBDV для цесарки не является патогенным.

\section{References}

CHUI, C. H. - THORSEN, J.: Experimental infection of turkey with infectious bursal disease virus and the effect on the immunocompetence of infected turkeys. Avian Dis., 28, 1984: 197-207.

EDGAR, S. A. - CHO, Y.: Avian nephrosis (Gumboro disease) and its control by immunization. Poult. Sci., 44, 1965: 1366.

FRITZSCHE, K. - HEFFELS, U. - KALETA, E. F.: Virusbedingte Infektionen der Taube. Dt. tierarzt1. Wschr., 88, 1981: 72-76.

HIROSE, M. - HIRAI, K.: Precipitating antibody against infectious bursal disease virus in egg yolk and serum of chickens. Res. Bull. Fac. Agric. Gifu University, 39, 1976: 165-170.

HOWIE, R. I. - THORSEN, J.: Identification of a strain of infectious bursal disease virus isolated from mosquitoes. Can. J. Comp. Med., 45, 1981: 315-320.

IDE, P. R.: A comparison of gel diffusion, fluorescent antibody and virus isolation methods in experimental and natural cases of infectious bursal disease. Can. J. Comp. Med., 39, 1975: 183-190.

LOUZIS, C. - GILLET, J. P. - IRGENS, K. - JEANIN, A. - PICAULT, J. P.: La maladie de Gumboro apparition chez le faisan d elevage. Bull. Mens. Soc. Vet. Prat. Fr., 63, 1979: 785-789.

MARQUARDT, W. W. - JOHNSON, R. B. - DENWALD, W. F. - SCHLOTTHOBER, B. A. : An indirect enzyme-linked immunosorbent assay (ELISA) for measuring antibodies in chicken infected with infectious bursal disease virus. Avian Dis., 24, 1980: 375-385.

McNULTY, M. S. - ALLAN, G. M. - McFERRAN, J. B.: Isolation of infectious bursal disease virus from turkeys. Avian Path., 8, 1979: 205-212.

NAWATHE, D. R. - ONUNKWO, O. - SMITH, I. M.: Serological evidence of infection with virus of infectious bursal disease in wild and domestic birds in Nigeria. Vet. Rec., 102, 1978: 444.

OKOYE, J. O. A.: Infectious bursal disease of chickens. Vet. Bu11., 54, 1984: $425-436$. 
OKOYE, J. O. A.: Absence of serological evidence of infectious bursal disease virus infection in geese, ducks and guinea fowls in Nsukka, Nigeria. Zariya Veterinarian 1988: In press.

OKOYE, J. O. A. - UZOUKWU, M.: An outbreak of infectious bursal disease among chickens between 16 and 20 weeks old. Avian Dis., 25, 1981: 1034-1038.

PERELMAN, B. - HELLER, E. D.: Preliminary serological survey of infectious bursal disease in turkey flocks in Israel. Refuah Vet., 38, 1981: 12-16.

PERELMAN, B. - HELLER, E. D.: The effect of infectious bursal disease virus on immune system of turkeys. Avian Dis., 27, 1983: 66-76.

PHILLIPS, W. E., Jr.: Comparison of precipitation antibodies and virus-neutralizing antibodies to infectious bursal disease virus. Avian Dis., 25, 1981: 1093-1097.

REED, L. J. - MUENCH, H.: A simple method of estimating $50 \%$ end points. Am. J. Hyg., 27, 1938: 493-497.

WEISMAN, J. - HITCHNER, S. B.: Infectious bursal disease virus infection in turkeys and Coturnix quail. Avian Dis., 22, 1978: 604-609.

YAMADA, S. - MATSUO, K. - UCHINUNO, Y.: Susceptibility of ducks and duck-origin cell cultures to infectious bursal disease virus. Avian Dis., 26, 1982: 596-601. 